prolonged training in this experiment (about 1,000 trials) was to entrench the avoidance responding. The no treatment control rats frequently did not "extinguish" responding, but met criterion by apparently being so fatigued that they could no longer climb to the shelf. Considering that 100 responses takes about an hour to complete and considering that these rats took a mean of 1,100 trials to extinguish, it is no wonder that after $11 \mathrm{~h}$ of responding they stopped.

A claim made for implosion therapy (flooding or response prevention) is that it is the technique of choice for more established, engrained, and more "dynamically" related phobias. Our data do not support the idea that implosion is the technique of choice for reducing well-established "avoidance." On the contrary, out data indicate that a counterconditioning procedure is the superior technique for reduction of entrenched as well as recently established avoidance.

\section{REFERENCES}

Baum, M. An automated apparatus for the avoidance training of rats. Psychological Reports, 1965, 16, 1205-1211.

Baum, M. Efficacy of response prevention (flooding) in facilitating the extinction of an avoidance response in rats: The effect of overtraining the response. Behavior Research \& Therapy, 1968, 6, 197-203.
Baum, M. Extinction of avoidance responding through response prevention (flooding). Psychological Bulletin, 1970, 74, 276-284.

Buss, R. S , \& Reid, L. D. Deconditioning persisting avoidance: Spacing counterconditioning periods during response prevention. Bulletin of the Psychonomic Society, 1973, 2, 418-420.

Gordon, A., \& Baum, M. Increased efficacy of flooding (response prevention) in rats through positive intracranial stimulation. Journal of Comparative \& Physiological Psychology, 1971, 75, 68-72.

Hunsicker, J. P., Nelson, T. C., \& Reid, L. D. Two kinds of intracranial stimulation as counterconditioners of persisting avoidance in rats. Physiological Psychology, 1973, 1, 227-230.

Prado-Alcala, R., Bush, H., Steele, D., \& Reid, L. Brief flooding and counterconditioning as treatments for persisting avoidance. Phy siological Psychology, 1973, 4, 389-393.

Reid, L. D. Processes of fear reduction in systematic desentization: An addendum to Wilson and Davison (1971). Psych ological Bulletin, 1973, 79, 107-109.

Wilson, E. H., \& Davison, G. C. Processes of fear reduction in systematic desensitization: Animal studies. Psychological Bulletin, 1971, 76, 1-14.

Winer, B. Statistical principles in experimental design. New York: McGraw-Hill, 1962.

(Received for publication February 11, 1974.)

\title{
Repetition effects and retroactive facilitation: Immediate and delayed recall performance*
}

\author{
DONALD ROBBINS $\dagger$ and JAMES F. BRAY \\ Emory University, Atlanta, Georgia 30322
}

\begin{abstract}
A study was conducted using a continuous paired-associate task varying the retention interval after one of two presentations of a pair of words. The lag between presentations was also varied. Half of the two presentation items represented an A-B, A-C negative transfer design while the other half were A-B, A-B items. Two different groups were instructed, with regard tc the A-B, A-C items, to recall on test trials only Response B or only Response C. Under some A-B, A-C conditions, retroactive facilitation was found. Specifically, with a relatively long retention interval and short lags, the presentation of A-C was as effective as a second presentation of $A-B$ for the recall of $B$.
\end{abstract}

It has been shown that increasing the spacing or lag between repetitions of a word pair leads to better recall performance on a paired-associate task (see Bjork, 1970;

*This research was supported by Grant MH 20331 from the National Institute of Mental Health.

tReprint requests should be sent to: Donald Robbins, Department of Psychology, Emory University, Atlanta, Georgia 30322 .
Melton, 1970). However, both Peterson, Wampler, Kirkpatrick, and Saltzman (1963) and Young (1971) reported a limit to this "spacing" effect, namely, at very long lags performance declined. Hence, the function relating proportion recalled and the lag between repetitions (for relatively long retention intervals) is concave downward. Furthermore, Peterson, Hillner and Saltzman (1962) found the spacing effect only when the 
Table 1

Retroactive Effects: Proportion Recalled of Response $B$ for the A-B, A-B and A-B, A-C Conditions

\begin{tabular}{|c|c|c|c|c|c|c|}
\hline \multirow[b]{2}{*}{$\begin{array}{c}\text { Retention } \\
\text { Interval }\end{array}$} & \multirow[b]{2}{*}{$\begin{array}{c}\mathrm{Lag} \\
\text { (in sec) }\end{array}$} & \multicolumn{2}{|c|}{$\begin{array}{l}\text { Immediate } \\
\text { Tests }\end{array}$} & \multicolumn{2}{|c|}{ Delay̌ed } & \multirow[t]{2}{*}{ Tests } \\
\hline & & $\begin{array}{l}A-B, \\
A-B\end{array}$ & $\begin{array}{l}A-B, \\
A-C\end{array}$ & $\begin{array}{l}\text { A-B, } \\
\text { A-B }\end{array}$ & $\begin{array}{l}A-B, \\
A-C\end{array}$ & \\
\hline $\begin{array}{l}\text { Short } \\
\text { (5 or } \\
10 \mathrm{sec})\end{array}$ & $\begin{array}{r}5 \\
10 \\
25 \\
50\end{array}$ & $\begin{array}{l}.75 \\
.52 \\
.58 \\
.46\end{array}$ & $\begin{array}{l}.48 \\
.31 \\
.18 \\
.18\end{array}$ & $\begin{array}{l}.13 \\
-- \\
.21 \\
--\end{array}$ & $\begin{array}{l}.16 \\
-- \\
.08 \\
--\end{array}$ & $\begin{array}{l}(.07)^{*} \\
(.08)\end{array}$ \\
\hline $\begin{array}{l}\text { Long } \\
\text { ( } 25 \text { or } \\
50 \mathrm{sec})\end{array}$ & $\begin{array}{r}5 \\
10 \\
25 \\
50\end{array}$ & $\begin{array}{l}.28 \\
.45 \\
.38 \\
.32\end{array}$ & $\begin{array}{l}.31 \\
.44 \\
.29 \\
.18\end{array}$ & $\begin{array}{l}.14 \\
-27 \\
.27 \\
--\end{array}$ & $\begin{array}{l}.12 \\
-\overline{17} \\
.17 \\
--\end{array}$ & $\begin{array}{l}(.13) \\
(.24)\end{array}$ \\
\hline
\end{tabular}

*These values represent the proportion recalled of Response $B$ on delayed tests for $S$ s told to recall only Response $C$ on the immediate tests.

retention interval was relatively long. When the retention interval was relatively short, performance declined as the lag increased. In the present study we report a replication of the interaction between lag and retention interval as well as the concave downward function in a continuous paired-associated task. In addition, delayed recall tests were also given to determine if these functional relations would be found after a considerably long interval followed the immediate-retention test. Additional conditions conformed to a negative transfer paradigm, i.e., the first presentation of a pair of words, A-B, was followed after a lag by a presentation of A-C rather than A-B. Recently, Robbins and Bray (in press) found retroactive facilitation under some conditions. When the lag was short and the retention interval was long, the recall of $B$ for $A-B, A-C$ items was equal to that for identical repetitions, A-B, A-B. Further, Bruce and Weaver (1973), using a paired-associate probe technique, found facilitated recall of $B$ in an A-B, A-C, A-C paradigm relative to an A-B, D-C, D-C control. The present study included longer lags and retention intervals than in the earlier studies and included delayed recall tests as well.

\section{METHOD}

\section{Design and Material}

A continuous paired-associate study-test procedure was used. The stimuli were medium imagery nouns, mean $=3.99$ (Paivio, Yuille, \& Madigan, 1968). There were 10 conditions. Two of the conditions were single-presentation controls, A-B, followed by one or five pairs or tests of other pairs and then a test trial. Since the trials were given at a 5 -sec rate, the retention interval was 5 and $25 \mathrm{sec}$, respectively, for these conditions. There were four repetition conditions representing a factorial combination of a lag of either 5 or $25 \mathrm{sec}$, and a retention interval of 5 or $25 \mathrm{sec}$. For these four conditions the same response was paired with a given stimulus on both presentations, i.e., A-B, A-B conditions. The last four conditions were also a factorial combination of lag $(5$ or $25 \mathrm{sec})$ and retention interval $(5$ or $25 \mathrm{sec})$. However, these four conditions conformed to an A-B, A-C paradigm. There were six replications of the experimental lis ${ }^{+}$. Filler items were inserted where necessary to obtain the appropriate spacing conditions. Approximately half of the filler items conformed to an A-B paradigm and the remaining items to an A-B, A-B paradigm. All of the filler items were tested although these data are not inlcuded in the analyses. The order of conditions was counterbalanced throughout the list and each $S$ had a different random order. The first 12 items in the list were a practice series which also served as a primacy buffer. The Ss were divided into two groups of 25 each, and were told that, with regard to the A-B, A-C pairs, either the first (Recall B) or the second (Recall C) pairing was considered correct on a test trial.

Since it was desired to use relatively long lags and retention intervals and also to obtain six replications per condition per $S$, an additional $50 \mathrm{Ss}$ were run. They were also divided into two groups, as above, with regard to the A-B, A-C items, namely, Recall B or Recall C. For these 50 Ss the retention interval for the A-B conditions was 10 or $50 \mathrm{sec}$. The factorial combination of lag and retention interval was for 10 and $50 \mathrm{sec}$ rather than 5 and $25 \mathrm{sec}$ for the A-B, A-B, and A-B, A-C items. For purposes of statistical analyses, each $S$ in the 5- and 25-sec condition was randomly yoked with an $S$ in the 10 - and 50 -sec condition, although the degrees of freedom were not increased. This yielded two groups of 25 , each treated differentially only with regard to the A-B, A-C items.

\section{Subjects}

A total of 100 Ss were obtained from the introductory psychology $S$ pool and partially fulfilled a course requirement by participation in a 45-55-min session. The Ss were run in small groups of up to five people.

\section{Procedure}

The study and test trials were presented visually at a 5 -sec rate with a Kodak Carousel projector, and each $\mathrm{S}$ recorded responses on a separate answer sheet. After the completion of the task, the Ss in the 5- and 25-sec condition were given a sheet which contained the stimulus terms from all of the experimental pairs in a random order. They were asked to write down as many of the responses they could remember, and for those stimuli that had had two responses associated with them to record both responses. The Ss were given about $5 \mathrm{~min}$ for this delayed recall test.

\section{RESULTS AND DISCUSSION}

Table 1 shows the proportion recalled of $B$ for the A-B, A-B and A-B, A-C conditions.

\section{Repetition Effects}

Performance on the A-B, A-B conditions on the immediate tests is shown in the third column in Table 1. An analysis of variance was performed comparing the two groups (Recall B and Recall C) on the proportion correct for the factorial combination of lag and retention interval. The lag effect was significant, $F(3,48)$ $=4.99, \mathrm{p}<.01$; the retention interval effect was also significant, $F(1,48)=128.0, p<.001$, as was the interaction between the two effects, $F(3,48)=5.81$, $p<.01$. However, the group effect was not significant, $\mathrm{F}<1$. Thus we replicated the interaction found by Peterson et al (1962) between lag and retention interval. We also replicated the limit found by Peterson et al (1963) and by Young (1971) for the spacing effect.

\section{Retroactive Effects}

Table 1 also shows that the proportion of $B$ recalled for the A-B, A-C items (Column 4) with a long retention 
Table 2

Proactive Effects: Proportion Recalled of Response $C$ for the A-B, A-C and Single Presentation Control Conditions

\begin{tabular}{|c|c|c|c|c|c|}
\hline \multirow[b]{2}{*}{$\begin{array}{l}\text { Retention } \\
\text { Interval }\end{array}$} & \multirow{2}{*}{$\begin{array}{c}\text { A-B, A-C } \\
\text { Lag } \\
\text { (in sec) }\end{array}$} & \multicolumn{2}{|c|}{$\begin{array}{c}\text { Immediate } \\
\text { Tests } \\
\end{array}$} & \multicolumn{2}{|c|}{ Delayed Tests } \\
\hline & & $\begin{array}{l}\text { A-B, } \\
\text { A-C }\end{array}$ & SPC* & $\mathrm{A}-\mathrm{B}, \mathrm{A}-\mathrm{C}$ & SPC* \\
\hline $\begin{array}{l}\text { Short } \\
\text { (5 or } \\
10 \mathrm{sec})\end{array}$ & $\begin{array}{r}5 \\
10 \\
25 \\
50\end{array}$ & $\begin{array}{l}.48 \\
.25 \\
.46 \\
.30\end{array}$ & $\begin{array}{l}.42 \\
.32 \\
.42 \\
.32\end{array}$ & $\begin{array}{ll}.09 & (.02) \dagger \\
-- & \\
.03 & (.10) \\
- & \end{array}$ & $\begin{array}{l}.11 \\
-11 \\
.-\end{array}$ \\
\hline $\begin{array}{l}\text { Long } \\
(25 \text { or } \\
50 \mathrm{sec})\end{array}$ & $\begin{array}{r}5 \\
10 \\
25 \\
50\end{array}$ & $\begin{array}{l}.18 \\
.22 \\
.30 \\
.14\end{array}$ & $\begin{array}{l}.27 \\
.28 \\
.27 \\
.28\end{array}$ & $\begin{array}{ll}.03 & (.04) \\
-- & \\
.12 & (.07) \\
-- & \end{array}$ & $\begin{array}{l}.13 \\
-- \\
.13 \\
--\end{array}$ \\
\hline
\end{tabular}

*Single presentation control: These control values are single presentation items with a retention interval equal to the time between $A-C$ and the retention test. Reading down the column, the retention intervals are $5,10,5,10,25,50,25$, and $50 \mathrm{sec}$, respectively.

tThe proportions in parentheses represent the proportion recalled of $C$ on delayed tests for $S$ s told to recall only $B$ on immediate tests.

interval was approximately equal to that of the A-B, A-B items when the lag was relatively short. This was confirmed by an analysis of variance comparing the proportion of $B$ recalled for the $A-B, A-C$ conditions and the A-B, A-B conditions. Although the statistical analyses reported in this section are not independent of those reported earlier, the levels of significance obtained are such as to minimize interpretative problems. The analysis revealed a significant interaction between condition and lag for the long retention interval, $F(1,24)$ $=9.74, p<.001$. Therefore, when a presentation of A-C followed A-B by 5 or $10 \mathrm{sec}$, it was as effective as a second presentation of $\mathrm{A}-\mathrm{B}$ when this presentation was followed by a long retention interval. On the other hand, when there was a short retention interval, the A-B, A-B conditions were superior to the corresponding A-B, A-C conditions. These results confirm the previous findings of retroactive facilitation under similar conditions (Robbins \& Bray, in press). Analysis of the delayed recall tests revealed that these findings, as shown in Table 1 , were essentially the same as on the immediate tests. Also shown in Table 1, in parentheses, are the proportion recalled of $B$ on the delayed test for those Ss told to recall only Response $\mathrm{C}$ on immediate tests. These data are similar to those of Robbins and Bray (in press) who found, on immediate tests, that a group told to recall both responses, $\mathrm{B}$ and $\mathrm{C}$, yielded the same level of recall as groups told to recall only $\mathrm{B}$ or only $\mathrm{C}$.

\section{Proactive Effects}

Table 2 shows the mean proportion of $\mathrm{C}$ recalled for the A-B, A-C conditions and the single presentation controls. In all but one case (the 5-sec retention condition), more responses were recalled for the control condition than for any of the A-B, A-C conditions. A similar result was found on delayed tests, as shown in Table 2. In addition the level of recall of $\mathrm{C}$ for Ss told to recall only B on immediate tests is also shown.

The findings of retroactive facilitation is surprising in light of the traditional findings of retroactive interference (e.g., Keppel, 1968). In the present study, as well as in Robbins and Bray (in press), a traditional "inferference" paradigm, A-B, A-C recall B, yielded the same level of recall as a repetition condition, A-B, A-B. Retroactive facilitation was found when two conditions were present: a long retention interval and a short lag. Recently, Bruce and Weaver (1973) also found retroactive facilitation with $\mathrm{A}-\mathrm{B}, \mathrm{A}-\mathrm{C}, \mathrm{A}-\mathrm{C}$ and $\mathrm{A}-\mathrm{B}, \mathrm{A}-\mathrm{C}$, A-D paradigms relative to A-B, D-C, D-C controls. Two kinds of facilitation should be noted. The first is the facilitation of an A-B, A-C paradigm relative to a control, A-B, D-C (Bruce \& Weaver, 1973; Robbins \& Bray, in press). The second regards the amount of facilitation as revealed by the comparison of an A-B, A-C paradigm to an identical repetition (Robbins \& Bray, in press). As both Bruce and Weaver (1973) and Robbins and Bray (in press) pointed out a modification of the Atkinson and Shiffrin (1968) limited-rehearsal buffer notion may accommodate these findings.

It should be noted that in all of the research indicating retroactive facilitation Ss are informed of the nature of A-B, A-C items prior to input. The role of instructions must be evaluated before any conclusions can be drawn.

\section{REFERENCES}

Atkinson, R. C., \& Shiffrin, R. M. Human memory: A proposed sy stem and its control processes. In $K$. W. Spence and J. T. Spence (Eds.), The psychology of learning and motivation: Advances in research and theory. Vol. 2. New York: Academic Press, 1968.

Bjork, R. A. Repetition and rehearsal mechanisms in models for short-term memory. In D. A. Norman (Ed.), Models of human memory. New York: Academic Press, 1970.

Bruce, D., \& Weaver, G. E. Retroactive facilitation in short-term retention of minimally learned paired associates. Journal of Experimental Psychology, 1973, 100, 9-17.

Keppel, G. Retroactive and proactive inhibition. In T. R. Dix on and $\mathrm{D}$. L. Horton (Eds.), Verbal behavior and general behavior theory. Englewood Cliffs, New Jersey: Prentice-Hall, 1968.

Melton, A. W. The situation with respect to the spacing of repetitions and memory. Journal of Verbal Learning \& Verbal Behavior, 1970, 9, 596-606.

Paivio, A., Yuille, J. C., \& Madigan, S. Concreteness, imagery, and meaningfulness values for 925 nouns. Journal of Experim ental Psychology, 1968, 76(1, pt. 2).

Peterson, L. R., Hillner, K., \& Saltzman, D. Time between pairings and short-term retention. Journal of Experimental Psychology, 1962, 64, 550-551.

Peterson, L. R., Wampler, R., Kirkpatrick, M., \& Saltzman, D. Effect of spacing presentations on retention of a paired associate over short intervals. Journal of Experimental Psychology, 1963, 66, 206-209.

Robbins, D., \& Bray, J. F. The spacing effect and the A-B, A-C paradigm: Evidence for retroactive facilitation. Journal of Experimental Psychology, in press.

Young, J. L. Reinforcement-test intervals in paired-associate learning. Journal of Mathematical Psychology, 1971, 8, 58-85.

(Recieved for publication February 1, 1974.) 